\title{
Assessing the effect of decopmression surgery performed due to malignant ischemic stroke on the quality of life
}

\section{Malign iskemik inmede dekompresyon cerrahinin yaşam kalitesi üzerine etkisinin değerlendirilmesi}

${ }^{1}$ Asst. Prof, Ataturk University, Faculty of Medicine, Department of Neurology, Erzurum,Turkey.

${ }^{2}$ Assoc. Prof, Ataturk University, Faculty of Medicine, Department of Neurology, Erzurum,Turkey.

${ }^{3}$ Asst. Prof, Ataturk University, Faculty of Medicine, Department of Neurosurgery, Erzurum,Turkey.

Sorumlu Yazar: Fatma Şimşek, Ataturk University, Asst. Prof., Faculty of Medicine, Department of Neurology, Erzurum, Turkey. E-mail:klamaks@hotmail.com Telefon: 05058347780.

Başvuru Tarihi: 01.04.2021 Kabul Tarihi: 16.06.2021 Yayınlanma Tarihi: 28.06.2021

Atff Iç̧in: Fatma Şimşek, Nuray Bilge, Mehmet Nuri Koçak, Mustafa Ceylan, Alper Eren, Recep Yevgi, Nuh Çağrı Karaavcı, Assessing the effect of decopmression surgery performed due to malignant Ischemic stroke on the quality of life, 2021;5(2):103-108

\section{ABSTRACT}

Aim: Decompressive craniectomy is one of the treatment methods that reduces mortality, when used in eligible patients for the treatment of malignant ischemic stroke (MIS). In this study, we aimed to assess the effect of age and the timing of surgery on the quality of life and on the prognosis of patients that underwent decompressive craniectomy.

Material and Method: The files of 45 patients between the ages of 24-98, who were recommended decompressive craniectomy in connection with malignant ischemic stroke, were reviewed within the scope of the study.

Result: 27 (60\%) patients, who agreed to undergoing surgery, and 18 (40\%) patients, who did not agree to undergoing surgery, were taken under review. A significant improvement (between 0 and 3) was observed in the modified Rankin Scale Scores of the two patients that underwent surgery. All the patients $(n=4)$ from within the group of patients that did not agree to a surgery, who lived for more than 6 months, were found to have a modified Rankin Scale Score of 5 and needed support to fulfill their daily life activities.

Conclusion: It has been observed that performing a decompressive craniectomy after 72 hours following clinical deterioration and radiological shift did not have a significant effect on mortality and morbidity. Studies with larger patient groups are needed to be carried out in order to determine the applicability criteria of surgical treatment.

Keywords: stroke; decompressive craniectomy;prognosis;mortality

\section{öz}

Amaç: Dekompressif kraniektomi malign iskemik inme tedavisinde uygun hastalarda kullanıldığında mortaliteyi azaltan tedavi yöntemlerinden biridir. Çalışmamızda dekompressif kraniektomi yapılan hastalarda operasyon zamanı ve yaşın, yaşam kalitesi ve prognoz üzerine etkisinin değerlendirilmesi amaçlanmıştır.

Gereç ve Yöntem: Malign iskemik inme nedeni ile dekompressif kraniektomi önerilen 24-98 yaş aralığında, 45 hastanın dosyası incelendi. Hastalar cerrahi yapılan ve cerrahiyi kabul etmeyerek sadece konservatif tedavi uygulanan iki gruba ayrılarak değerlendirildi.

Bulgular: Operasyonu kabul eden $n=27$ (\%60) hasta ve operasyonu kabul etmeyen $n=18(\% 40)$ hasta incelendi. Cerrahi yapılan grupta iki hastanın modifiye Rankin Skorunda belirgin iyileşme görüldü (0-3 arasında). Cerrahiyi kabul etmeyen grupta 6 aydan uzun süre yaşayan hastaların hepsinde $(n=4)$ modifiye Rankin Skoru: 5 olup günlük yaşam aktivitelerinde desteğe ihtiyaçları vardı.

Sonuç: Klinik kötüleşme ve radyolojik olarak şift görüldükten 72 saat sonra yapılan dekompresif kraniektominin mortalite ve morbidite üzerinde anlamlı bir etkisinin olmadığı görülmektedir. Cerrahi tedavinin uygulanabilirlik kriterlerini belirlemek için daha büyük hasta grupları ile yapılacak çalışmalara ihtiyaç vardır.

Anahtar Kelimeler: inme;dekompressif kraniektomi;prognoz;mortalite 


\section{INTRODUCTION}

Stroke is the second most common cause of death worldwide, and the first cause of acquired disability in adults $(1,2)$. Malignant ischemic stroke (MIS) is characterized by progressive cerebral oedema, which may lead to insufficient blood flow, increased intracranial pressure, brain herniation, and death (3). The signs of malignant ischemic stroke are that 50$75 \%$ of the middle cerebral artery (MCA) area, including the basal ganglia, become hypodense, that additional vascular areas get affected, and that a cerebral midline shift of more than $4 \mathrm{~mm}$ occurs at the pineal gland level within the first 48 hours from the time of the ischemic stroke $(4,5)$. Mortality rate may go up to as high as $70-80 \%$ in patients with large ischemic lesions lesions $(6,7)$ whereas serious residual disability is often observed in the surviving patients. 8 Intravenous thrombolysis along with the recombinant tissue plasminogen activator (rt-PA) applied within the first 4.5 hours after the onset of the symptoms may significantly improve patients' outcomes (9). Medical treatments directed at MIS do not always yield satisfactory results and patients may have no other choice but to undergo surgical treatment. Decompressive craniectomy (DC) is one of these surgical treatment options directed at MIS. With DC, part of the skull is surgically removed in order to allow oedematous brain tissue to herniate in the outward direction, and in this way, it is tried to prevent the occurence of neuronal damage in other parts of the brain $(10,11)$. DC reduces the mortality rate by $<20 \%$ in patients with MIS $(12)$.

The aim of our study is to assess the effect of DC performed due to MIS on quality of life and prognosis.

\section{MATERIAL and METHODS}

\section{Selection of Patients}

The files of patients, who were hospitalized due to MIS in the neurology clinic of Atatürk University School of Medicine between January 2017 and April 2019, were analyzed retrospectively. Patients over the age of 18 that underwent DC and who had a midline shift of at least $0.5 \mathrm{~cm}$ in the computed tomography (CT) and presented clinical deterioration were included in the study along with the patients who received conservative treatment as the sole treatment option. Patients with a Glasgow Coma Scale (GCS) score below 7 and a Barthel index below 95 prior to the ischemia were not included in the study. Demographic data, clinical findings, accompanying systemic diseases, Glasgow Coma Scale (GCS) scores, modified Rankin Scale (mRS) scores, infarct localization, the treatments applied and the times that the patients underwent DC were recorded. The surgical operation was performed on the patients through a large fronto-temporo-parietal incision (Figure 1).

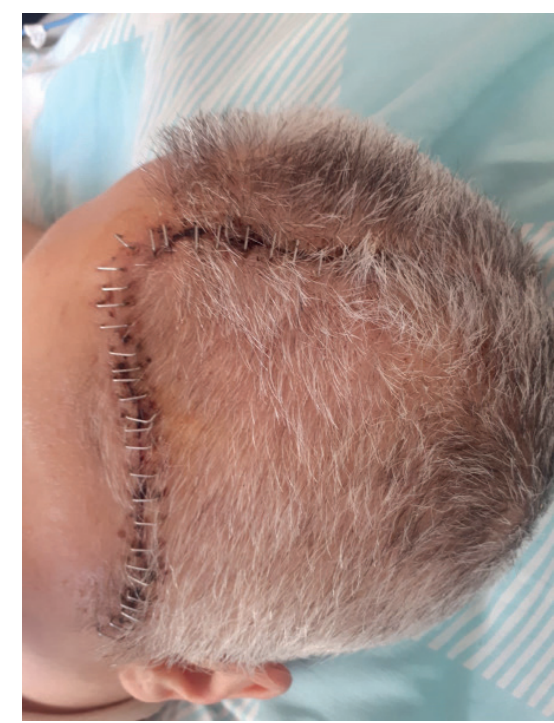

Figure 1: An image that belongs to a 36-year-old female patient who underwent decompressive craniectomy due to malignant ischemic stroke through a left fronto-temporo-parietal incision.

\section{Statistical analysis}

All statistical analyses were carried out using the SPSS 20 software. The normal distribution of the data was analyzed using the Kolmogorov-Smirnov test. Mann-Whitney $\mathrm{U}$ test was used for comparisons between groups. Categorical variables were compared using the chi-square test. The Kruskall Wallis test was used in the comparison of multiple independent groups (for the comparison of the difference between the postoperative mRS scores and the survival times with respect to the three groups formed according to the timing of the surgery and the difference between the treatment applied in the conservative treatment group and the survival times), and the Wilcoxon test was used in the comparison of the two dependent groups (for the comparison of preoperative and postoperative mRS scores). Spearman correlation coefficients were calculated in order to evaluate the relationship between the survival time and other parameters. Numerical variables were reported as mean \pm Std. Dev., median (min-max), whereas the categorical variables were reported as $n(\%)$. Probability (p) values of less than 0.05 were accepted to indicate statistical significance $(p<0.05)$.

Ethics Committee Approval: Approval for this study was obtained from the Ataturk University School of Medicine Clinical Research Ethics Committee (02/32/27.02.2020). 
$27(60 \%)$ patients, who agreed to undergoing surgery due to MIS, in addition to the $18(40 \%)$ patients, who did not agree to undergoing surgery, were taken under review. The mean age of the patients was $66.25 \pm 16.5$ years. $66.7 \%$ $(n=30)$ of the patients were female and $33.3 \%(n=15)$ of the patients were male. $58.8 \%(n=20)$ of the patients, who underwent surgery, and $41.2 \%(n=14)$ of the patients, who did not undergo surgery, died within the first 6 months from the time of the ischemic stroke. The clinical and demographic data of the patients, who underwent surgery due to MIS, and of the patients that didn't, are given in Table 1, whereas the relationship between the clinical data of the patients that underwent surgery and their survival times are given in Table 2. Of the patients who underwent DC after ischemia, $25.93 \%(n=7)$ of them underwent surgery within the first 24 hours from the time of the ischemic stroke, 33.33\% $(n=9)$ of them underwent surgery within the period of 24 to 72 hours from the time of the ischemic stroke, and $40.74 \%(n=11)$ of them underwent surgery after 72 hours from the time of the ischemic stroke. No statistically significant difference was found between the three groups formed according to the timing of the surgery in terms of postoperative mRS scores and survival times ( $p=0.41, p=0.39$; respectively). On the other hand, a statistically significant difference was found between the preoperative and postoperative mRS scores of the patients with reference to their times of surgery. This difference was originated from the increase in the postoperative $\mathrm{mRS}$ scores, that is, the higher number of patients presenting postoperative clinical deterioration $(p=0.001)$. The reason for the difference between the preoperative and postoperative mRS scores was the patients who underwent surgery after 24 hours from the time of the ischemic stroke. It was observed that the $\mathrm{mRS}$ scores (mRS scores between 0-3) of two patients from within the group of patients that underwent surgery had improved following their discharge and that the respective patients could perform their daily life activities on their own, however that none of the patients' mRS scores from within the group of patients that did not agree to a surgery, had improved. All the patients $(n=4)$, who did not undergo DC but lived for more than 6 months from the time of the ischemic stroke, had an $\mathrm{mRS}$ score of 5 and needed support to perform their daily life activities. No significant correlation was found between timing of the surgery performed following ischemia and the postoperative mRS score of the patients that underwent surgery $(r=-0.05, p=0.79)$. The case study image of cases that underwent $D C$ and benefited from $D C$ is given $($ Figure 2,3$)$.

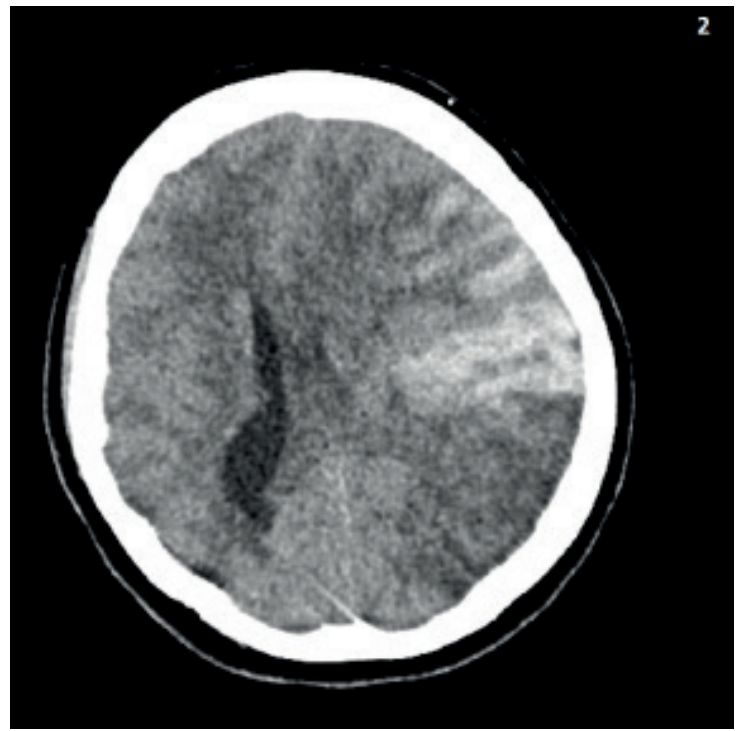

Figure 2: In the CT image of a 36-year-old female patient due to MIS, before performing decompressive craniectomy, hypodense infarction area in the left middle cerebral artery region and areas compatible with hyperdense bleeding, ventricular compression and subphaxian shift are observed.

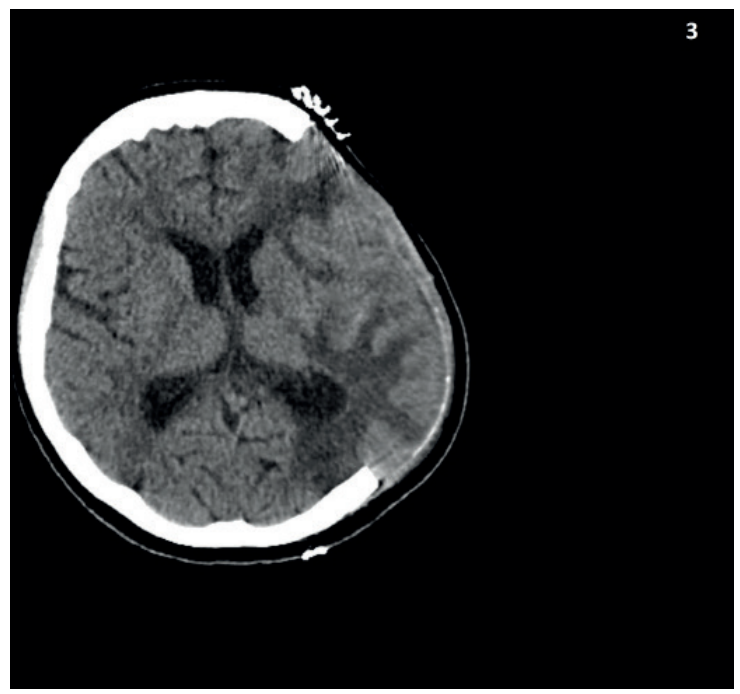

Figure 3: It has been observed during the follow-up visits of the same patient following DC that the ventricular compression had improved and that there are areas of hypodense infarct locally 


\section{DISCUSSION}

In this study, no statistically significant difference was found between the mortality and morbidity rates of patients that underwent or did not undergo DC due to MIS. It was observed that the mRS scores of two patients from within the group of patients $(n=7)$ that underwent surgery and lived for more than 6 months had improved and that these patients could perform their daily life activities without the need for any assistance, however that none of the patients' mRS scores from within the group of patients $(n=4)$ that did not agree to a surgery and lived for more than 6 months, had improved. There was a statistically significant difference between the groups of patients with and without coronary artery disease who underwent DC in terms of survival time, and the survival times were found to be longer in patients without coronary artery disease. There was no significant correlation between the timing of taking a patient under operation following ischemia and the postoperative mRS score.

Mortality rate is high in MIS due to brain oedema and herniation, whereas in surviving patients the rate of neurological sequelae is high. The fact that there are no established criteria in terms of age limit and timing of the surgery with respect to performing DC in MIS patients is confounding. There are only a few studies, in which the relationship between the timing of surgery and the results thereof have been studied. The fact that there are no established criteria in terms of age limit and timing of the surgery with respect to performing DC in MIS patients is confounding. There are not many studies, in which the relationship between the timing of surgery and the results thereof have been studied. For this reason, it was investigated in this study whether the timing of surgical treatment and the age of the patient affect the quality of life and whether there is a difference between the group of patients that underwent surgery and the group of patients that received conservative treatment in terms of life expectancy and quality of life.

It was reported in some studies that performing DC in early period is associated with less neurological deficits and returning to daily life activities earlier (13). Additionally, it was reported in other studies that delayed surgery is associated with a clinically poor outcome (14). In this study, no significant relationship was found between the timing of the surgery and the postoperative mRS score and the survival time ( $r=-0.05, p=0.79 ; r=-0.01, p=0.96$; respectively). However, a significant improvement was observed in the mRS scores of the two patients (both patients were among the patients, who were taken under operation within the first 72 hours from the time of ischemic stroke) included in the group of patients that underwent surgery, contrary to the case in the conservative treatment group, in which there was no patient with an improved mRS score. These two patients (aged 36 and 74)were able to continue their daily life activities without the need for any support. Kilıç et al. reported a statistically significant difference in their study between the preoperative and postoperative mRS scores of the patients who underwent surgery within the first 48 hours from the time of ischemic stroke (15). The number of patients that underwent surgery within the first 24 hours from the time of ischemic stroke were higher in the study of Kilıç et al. On the other hand, patients that are between the ages of 18-65 and presented within the first 72 hours from the time of ischemic stroke were investigated within the scope of the HeMMI (Hemicraniectomy for Malignant Middle Cerebral Artery Infarction) study, and no significant difference was found between the group of patients that underwent surgery and the group of patients that received conservative treatment in terms of mortality and morbidity (16). The results of this study were similar to the results reported in the HeMMI study, in the sense that there was also no significant difference between the group of patients that underwent surgery and the group of patients that received conservative treatment in terms of mortality and morbidity in this study. However, it is important to note that only the period of 72 hours from the time of ischemic stroke was investigated within the scope of the HeMMI study, and that the number of patients who were taken under operation after 72 hours from the time of ischemic stroke was higher in this study. This difference in results suggests that delayed surgery might be the reason for the lower success rate achieved in this study. It was demonstrated in DECIMAL (decompressive craniectomy in malignant middle cerebral artery infarcts), DESTINY (decompressive surgery for the treatment of malignant infarction of the middle cerebral artery) and HAMLET (hemicraniectomy after middle cerebral artery infarction with life-threatening edema trial) studies that performing a surgery within the first 48 hours from the time of ischemic stroke give more successful results in terms of mortality and morbidity (17-19). Patients over 60 years of age were not included in the DESTINY study and patients were not taken under operation after 36 hours from the time of ischemic stroke. This fact, taken together with the results of the said study, suggests that performing DC in an earlier period in patients that are not very old may give more successful results. It was reported in various studies that performing surgery in patients aged 80 years and younger in the first 48 hours from the time of ischemic stroke gives more successful results $(20,21)$. It can be said in the light of the results of all the aforementioned studies that there is no definite age limit for performing DC. Patients that underwent surgery and the patients that received conservative treatment were investigated within the scope of the DECIMAL study at the fourth week after the surgery or treatment, and the mortality rate was found as $16 \%$ in the group of patients that underwent surgery and as $33 \%$ in the group of patients that received conservative treatment (17). Another study compared the mortality rates in patients that underwent DC, as of the 6th and 12th months after the surgery, and the mortality rates in patients that received conservative treatment, as of the 6th and 12 th months after the treatment, and the mortality rates were found to be lower in the group of patients that underwent DC, in both cases. 20 Of the patients included in this study, $58.8 \%(n=20)$ of the patients who underwent $D C$ and $41.2 \%(n=14)$ of the patients who received conservative treatment died within the first 6 months from the time of ischemic stroke, and the mortality rate of the group of patients that underwent DC was found to be higher compared to the mortality rates reported in other studies for the corresponding group of patients. This difference in mortality rates might be due to the fact that the patients included in this study were older (oldest one being 87 years old) and the number of patients who underwent surgery after 72 hours from the time of ischemic stroke was higher. It was reported in another study that none of the patients with a cerebral infarct volume of above $390 \mathrm{~cm} 3$ had benefited from DC and it was therefore concluded that the patients with an infarct volume of $390 \mathrm{~cm}^{3}$ are not suitable for DC (22). The relationship between the mortality and morbidity rates and the volume was not compared in this study, as no volume calculations have been made. 
There are many systemic diseases in the etiology of patients with ischemic stroke. Of the patients included in our study, $\mathbf{7 7 . 7 8 \%}$ of them had at least one risk factor in etiology. The analysis of the relationship between the comorbid systemic diseases and the survival times in patients that underwent surgery revealed a statistical significant difference only between the groups with and without coronary artery disease in terms of survival times. Survival times were longer in patients without coronary artery disease than in those with coronary artery disease. These results suggest that coronary artery disease affects mortality more significantly in patients with ischemic stroke compared to other systemic diseases.

This study had some limitations, such as the fact that the number of cases included in the study was not high, that age range of the patients included in the study was too broad, and that it was a single-center and retrospective study.

\section{CONCLUSION}

No statistically significant difference was found as a result of this study between the group of MIS patients that underwent DC and the group of MIS patients that received conservative treatment in terms of mortality and quality of life. The majority of the surviving patients in both groups had severe neurological sequelae. The high rate of patients who underwent surgery in the late period and the fact that no improvement was observed in the mRS scores of patients who underwent DC after 72 hours from the time of ischemic stroke suggest that it would be more appropriate to continue follow-up with conservative treatment in these patients. Studies with larger patient groups are needed to be carried out in order to determine the applicability criteria of surgical treatment.

\section{ACKNOWLEDGMENT}

\section{Conflict of Interest: None}

Financial Support: No financial support was received for the study.

Ethics Committee Approval: Approval for this study was obtained from the Ataturk University School of Medicine Clinical Research Ethics Committee (02/32/27.02.2020).

\section{Authorship Contributions}

Concept: Şimşek F, Bilge N, Design; Şimşek F, Bilge N, Koçak MN, Eren A, Ceylan M, Yevgi R, Karaavcı NÇ

Collection or processing: Şimşek F, Bilge N, Eren A, Analysis or interpretation; Şimşek F, Bilge N, Koçak MN, Eren A,

Literature search: Şimşek F, Bilge N, Koçak MN, Eren A, Ceylan M, Yevgi R, Karaavcı NÇ,

Writing: Şimşek F, Bilge N, Koçak MN, Eren A, Ceylan M, Yevgi R, Karaavcı NÇ.

\section{REFERENCES}

1. Naghavi M, Abajobir AA, Abbafati C, Abbas KM, Abd-Allah F, Abera SF, et al. Global, regional, and national age-sex specific mortality for 264 causes of death, 1980-2016: a systematic analysis for the Global Burden of Disease Study 2016. The Lancet 2017; 390:1151-1210.DOI: 10.1016/S0140-6736(17)32152-9

2. Go A, Mozaffarian D, Roger V, Benjamin E, Berry J, Blaha M. Committee and Stroke Statistics Subcommittee. Heart disease and stroke statistics-2014 update: a report from the American Heart Association Circulation 2014; 129:e28-e292. DOI: 10.1161/01.cir.0000441139.02102.80

3. Frank Jl. Large hemispheric infarction, deterioration, and intracranial pressure. Neurology 1995; 45:1286-1290. DOI: 10.1212/WNL.45.7.1286

4. Kasner SE, Demchuk AM, Berrouschot Jr, Schmutzhard E, Harms L, Verro P, et al. Predictors of fatal brain edema in massive hemispheric ischemic stroke. Stroke 2001; 32:2117-2123. DOI: 10.1161/hs0901.095719

5. Pullicino P, Alexandrov A, Shelton J, Alexandrova N, Smurawska L, Norris J. Mass effect and death from severe acute stroke. Neurology 1997; 49:1090-1095. DOI: 10.1212/WNL.49.4.1090

6. Wijdicks EF, Sheth KN, Carter BS, Greer DM, Kasner SE, Kimberly WT, et al. Recommendations for the management of cerebral and cerebellar infarction with swelling: a statement for healthcare professionals from the American Heart Association/American Stroke Association. Stroke 2014; 45:1222-1238. DOI: 10.1161/01.str.0000441965.15164.d6

7. Wijdicks EF, Diringer MN. Middle cerebral artery territory infarction and early brain swelling: progression and effect of age on outcome. Elsevier 1998: 829-836. DOI: 10.4065/73.9.829

8. Lu X, Huang B, Zheng J, Tao Y, Yu W, Tang L, et al. Decompressive craniectomy for the treatment of malignant infarction of the middle cerebral artery. Scientific reports 2014; 4:1-9.

9. Moussaddy A, Demchuk AM, Hill MD. Thrombolytic therapies for ischemic stroke: Triumphs and future challenges. Neuropharmacology 2018; 134:272-279. DOI: 10.1016/j.neuropharm.2017.11.010

10. Kolias AG, Kirkpatrick PJ, Hutchinson PJ. Decompressive craniectomy: past, present and future. Nature Reviews Neurology 2013; 9:405-415. 
11. SchwabS, Rieke K, Aschoff A, AlbertF, von Kummer R, Hacke W. Hemicraniotomy in space-occupying hemispheric infarction: useful early intervention or desperate activism? Cerebrovascular Diseases 1996; 6:325-329. DOI: 10.1159/000108046

12. Wirtz CR, Steiner T, Aschoff A, Schwab S, Schnippering H, Steiner HH, et al. Hemicraniectomy with dural augmentation in medically uncontrollable hemispheric infarction. Neurosurgical Focus 1997; 2:E7. DOI: 10.3171/foc.1997.2.5.7

13. Vahedi K, Hofmeijer J, Juettler E, Vicaut E, George B, Algra A, et al. Early decompressive surgery in malignant infarction of the middle cerebral artery: a pooled analysis of three randomised controlled trials. The Lancet Neurology 2007; 6:215-222. DOI: $10.1016 /$ S1474-4422(07)70036-4

14. Dasenbrock HH, Robertson FC, Vaitkevicius H, Aziz-Sultan MA, Guttieres D, Dunn IF, et al. Timing of decompressive hemicraniectomy for stroke: a nationwide inpatient sample analysis. Stroke 2017; 48:704-711. DOI: 10.1161/ STROKEAHA.116.014727

15. Kilic M, Ertem DH, Ozdemir B. Timing of Decompressive Craniectomy for Malignant Middle Cerebral Artery Infarction: A Single-Center Analysis. Medicina 2019; 55:31. DOI: 10.3390/medicina55020031

16. Chua A, Buckley BS, Lapitan M, Jamora R. Hemicraniectomy for malignant middle cerebral artery infarction (HeMMI): a randomized controlled clinical trial of decompressive surgery with standardized medical care versus standardized medical care alone. Acta Med Philipp. 2015; 49

17. Vahedi K, Vicaut E, Mateo J, Kurtz A, Orabi M, Guichard JP, et al. Sequential-design, multicenter, randomized, controlled trial of early decompressive craniectomy in malignant middle cerebral artery infarction (DECIMAL Trial). Stroke 2007; 38:2506-2517. DOI: 10.1161/STROKEAHA.107.485235

18. Jüttler E, Schwab S, Schmiedek P, Unterberg A, Hennerici M, Woitzik J, et al. Decompressive surgery for the treatment of malignant infarction of the middle cerebral artery (DESTINY) a randomized, controlled trial. Stroke 2007; 38:2518-2525. DOI: 10.1161/STROKEAHA.107.485649

19. Hofmeijer J, Kappelle LJ, Algra A, Amelink GJ, van Gijn J, van der Worp HB. Surgical decompression for space-occupying cerebral infarction (the Hemicraniectomy After Middle Cerebral Artery infarction with Life-threatening Edema Trial [HAMLET]): a multicentre, open, randomised trial. The Lancet Neurology 2009; 8:326-333.DOI: 10.1016/S1474-4422(09)70047-X

20. Zhao J, Su YY, Zhang Y, Zhang YZ, Zhao R, Wang L, et al. Decompressive hemicraniectomy in malignant middle cerebral artery infarct: a randomized controlled trial enrolling patients up to 80 years old. Neurocritical care 2012; 17:161-171.DOI: $10.1007 / \mathrm{s} 12028-012-9703-3$

21. Jüttler E, Unterberg A, Woitzik J, Bösel J, Amiri H, Sakowitz OW, et al. Hemicraniectomy in older patients with extensive middle-cerebral-artery stroke. New England Journal of Medicine 2014; 370:1091-1100. DOI: 10.1056/NEJMoa1311367

22. Slezins J, Keris V, Bricis R, Millers A, Valeinis E, Stukens J, et al. Preliminary results of randomized controlled study on decompressive craniectomy in treatment of malignant middle cerebral artery stroke. Medicina 2012; 48:76. 